ELORE (ISSN 1456-3010), vol. 20 - 1/2013.

Julkaisija: Suomen Kansantietouden Tutkijain Seura ry.

[http://www.elore.fi/arkisto/1_13/lukin.pdf]

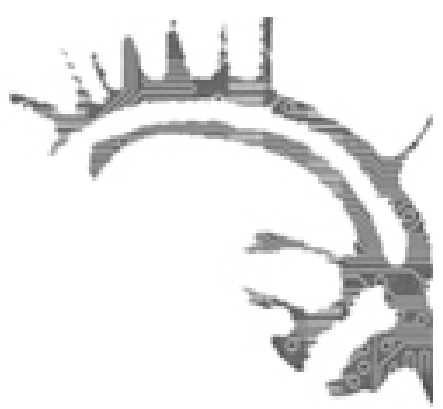

\title{
SEMINAARIRAPORTTI
}

\section{YKSITYISTÄ JA JULKISTA}

\author{
Karina Lukin
}

Private and Public Memories. The Fourth International Symposium of the Finnish Oral History Network. 29.-30.11.2012 Helsingissä

Suomen muistitietotutkijoiden verkoston (Finnish Oral History Network, lyhyemmin FOHN) neljäs kansainvälinen symposiumi kokosi Helsinkiin marraskuun 2012 lopulla yli 40 puhujaa ja lukuisia kuuntelijoita. Symposiumin teema, Private and Public Memories, oli järjestäjien mukaan herättänyt niin paljon kiinnostusta, että ainoastaan puolet abstraktinsa lähettäneistä kyettiin ottamaan mukaan puhujiksi. Laaja mielenkiinto ei kerro ainoastaan hyvin valitusta teemasta, vaan myös siitä pitkäjänteisestä työstä ja hedelmällisestä keskusteluympäristöstä, jonka FOHN:n aktiiviset toimijat ovat luoneet verkoston kymmenvuotisen toiminnan aikana. Symposiumin yleinen tunnelma olikin poikkeuksellisen rento ja avoin, ja niin pääpuhujien kuin rinnakkaisistuntojen esitelmöitsijöidenkin puheet ja ajatukset herättivät hyviä keskusteluja.

Symposiumin osallistujat saapuivat perinteiseen tapaan Suomen lähialueilta, erityisesti Baltian maista, mutta mukaan mahtui tutkijoita muualtakin Itä-Euroopasta, Britanniasta, Yhdysvalloista ja Australiasta. Kuten monitieteisen muistitietotutkimuksen luonteeseen kuuluu symposiumin osallistujat edustivat lukuisia tieteenaloja ja näkökulmia; osallistujia yhdistäviä teemoja olivat elämäkerrat, toiseen maailmansotaan ja sen seurauksiin - Neuvostoliittoon ja rautaesirippuun - liittyvät kertomukset sekä ryhmät, jotka kansallisissa historioissa on perinteisesti jätetty paitsioon. 
Karina Lukin: Yksityistä ja julkista

\section{MuISTITYöTÄ}

Symposiumin aloittanut professori Paula Hamiltonin (University of Technology) esitelmä toi esiin monia muistamiseen, haastatteluun ja nykyhetken ja menneen suhteeseen liittyviä keskeisiä näkökohtia, joita voidaan pitää muistitietotutkimuksessa yleisesti hyväksyttyinä. Hän muun muassa painotti haastatteluprosessin avaamisen tärkeyttä sen sijaan että itse haastattelun erinomaisuutta metodina korostettaisiin. Hamiltonin mukaan tutkijoiden tulisi tuoda esiin, miten muistityö (memory work) tapahtuu, toisin sanoen, miten yksityiset muistot siirtyvät haastattelun suhteellisen luottamuksellisesta hetkestä julkisiksi, kollektiivisesti jaettavaksi ja jaetuksi tiedoksi. Jotkut kertovat muistojaan ensimmäisen kerran elämässään, kun taas toiset voidaan luokitella muistitietoaktivisteiksi (memory activists). Tutkijan status vaihtelee varmasti suhteessa tällaisiin haastateltaviin, mutta mikä status on haastattelijalla ja haastattelulla juuri suhteessa symposiumin teemaan, yksityiseen ja julkiseen?

Hamilton toi myös hienosti esiin, miten kahtiajakautunut suhteemme henkilökohtaiseen on. Yhtäältä oral historynkin voi nähdä osana laajempaa prosessia, jossa kiinnostus yksityistä piiriä kohtaan on kasvanut julkisessa keskustelussa: näin ei ole ainoastaan keltaisessa lehdistössä, vaan myös esimerkiksi historiallisessa kirjallisuudessa tai tutkimuksessa, jossa keskitytään yhä enemmän yksityisiin kokemuksiin ja muistoihin. Sen sijaan poliittisessa toiminnassa suullisella historialla ja kokemuksella ei juuri ole Hamiltonin mukaan valtaa tai tilaa.

Hamilton kuvaili esitelmässään kokemuksiaan näyttelystä, jossa Australian menneisyyden kipupistettä, aboriginaalien ja erityisesti heidän lastensa kohtelua esiteltiin museossa. Näyttelyn taustalla oli vuonna 1981 julkaistu raportti, Stolen Generations (Read 1981), jonka seurauksena alkuperäisväestön lasten ja vanhempien erottamisista alettiin käydä julkista keskustelua. Julkaisussa ja sitä seuranneessa keskustelussa monet yksityiset muistot tulivat osaksi julkista ja lopulta myös osaksi virallista tietoa ja virallisia prosesseja: Australian vaivaton menneisyys sai uuden aboriginaalien kertomuksen sisältäneen luvun, joka omaksuttiin kollektiivisesti. Hamilton näytti, miten näitä traumaattisia muistoja visualisoitiin näyttelyssä, jossa museo haluttiin muuntaa pelkästä muistoja varastoivasta rakennuksesta muistoja luovaksi tilaksi ja prosessiksi, joka osallistuu julkiseen muisteluun ja luo virallista.

\section{YKSITYISEN JA JULKISEN RAJAT IDÄSSÄ}

Hamilton viittasi puheessaan kommunistisiin yhteiskuntiin esimerkkinä siitä, että julkisen ja yksityisen rajat ja sisällöt sijoittuvat eri diskursseissa eri tavoin. Symposiumin baltialaisten osallistujien esitelmissä tämä liikkuva ja liukuva raja ja sen mielikuvituksellinen hyödyntäminen neuvostoaikoina tulikin toistuvasti esiin. Myös professori Daniela Kolevan (Sofian yliopisto) esitelmä tarjosi vahvan ja monipuolisen taustan rautaesiripun takaisen muistelutaktiikan ymmärtämiselle. Hän eritteli Certeaun strategian ja taktiikan käsitteisiin pohjautuvalla näkökulmallaan Romanian Belenessä ja Sandanskissa rautaesi- 
ripun romahtamisen jälkeen toteutettuja muistitietoprojekteja. Koleva totesi aluksi, että niin julkinen kuin yksityinenkin syntyvät toiminnassa; hänen näkökulmansa muistiin ja muisteluun korosti ennen kaikkea niiden kollektiivisuutta ja identiteetin artikuloimisen ja legitimaation prosesseja.

Kolevan ensimmäinen esimerkki sijoittui Beleneen ja sen lähellä, Tonava-joen saarekkeella sijainneeseen Romanian suurimpaan työleiriin, joka on toiminut myöhemmin julkisessa muistelussa kommunistihallinnon sortotoimien ja GULAGin ${ }^{1}$ symbolina. Julkisen diskurssin puitteissa saarella ja saarta on muisteltu, leiriltä selviytyjiä on haastateltu ja esitelty dokumenteissa, romaaneissa ja elokuvissa. Belenen kaupungissa tehdyt haastattelut taas ovat antaneet aiheen puhua paikallisten kollektiivisesta muistinmenetyksestä: koko Belenen kaupungissa ei näy jälkeäkään leiristä, eikä kukaan osallistu leirin muistelemiseen, ei virallisesti eikä epävirallisesti. Sen sijaan Beleneä esitellään muinaisena roomalaislinnoituksena, luonnonsuojelualueena, katolilaisuuden ja ortodoksisuuden rauhanomaisen kohtaamisen paikkana ja ydinteollisuuden keskuksena. Monivuotisten haastattelujen aikana on kuitenkin käynyt ilmi myös, että mediassa esillä ollut julkinen muistelu on vaikuttanut beleneläisten henkilökohtaiseen muistiin: se on toiminut muistelun mallina niin, että mediassa esitetyt tarinat toistuvat henkilökohtaisina muistoina. Koleva purki tätä hienosti haastattelun mikropolitiikkana: haastateltavat ovat esittäneet omakuvaansa haastatteluissa koettamalla tavoittaa julkista diskurssia, mutta eivät yksioikoisesti sitä toistaen: muistelun strategiat ovat moninaisia erityisesti paikallisella tasolla.

\section{KIRJALLISET, SUULLISET}

Olin itse kuuntelemassa muun muassa apulaisprofessori Baiba Belan (Latvian yliopisto) esitelmää, joka eritteli yhtäältä haastattelun ja omaelämäkerrallisen tekstin välisiä eroja muistelussa ja toisaalta julkisen diskurssin ja yksityisen elämän kohtaamispaikkoja näissä teksteissä. Belankin esitelmä sijoittui menneeseen neuvostoyhteiskuntaan ja hänen esittelemänsä yksityishenkilön elämä ei edusta tavanomaista hyvin poikkeuksellisine käänteineen. Kuten monet suomalaiset, myös Bela käyttää aineistoinaan sekä suullisia että kirjallisia lähteitä ja esitelmässään hän osoitti, että näillä aineistoilla on monenlaisia eroja. Belan aineistot antoivat mahdollisuuden pohtia, miten yksi henkilö käyttää kirjallista ja suullista kanavaa oman elämänsä kertomiseen. Erot olivat jo pelkän pintaraapaisun perusteella hyvin moninaisia. Sekä kirjalliseen että haastattelussa tuotettuun muisteluun kietoutui aikaan, paikkaan ja vuorovaikutukseen liittyviä, merkityksiä tuottavia tekijöitä, jotka ovat edellyttäneet tarkkaa työtä muistitietotutkijalta.

Erityisesti symposiumin kansainvälisten osallistujien esitelmien aineistot olivat edelleen suurimmaksi osaksi suullisia, haastatteluissa tuotettuja ja usein todistajanlausunnon oloisia. Valittu teema antoi mahdollisuuden kohdistaa katse myös kirjoitettuihin aineistoihin, joita usein pidetään julkisina ja jonkinlaista virallista menneisyyden tulkintaa edustavina. Akatemiatutkija Kirsti Salmi-Niklanderin (Helsingin yliopisto) esitelmässä tarkasteltiin monitahoisesti sellaisia kirjallisia dokumentteja, jotka asettuvat suullisen ja kirjallisen välimaastoon. Salmi-Niklanderin esittelemät elämäkerralliset aineistot on 
julkaistu käsinkirjoitetuissa osakuntalehdissä, joiden esitelmöitsijä luonnehti sijoittuneen puolijulkiselle alueelle (semipublic sphere). Käsinkirjoitetut lehdet ovatkin toimineet 1800- ja 1900-lukujen vaihteessa varsin kapeassa julkisessa tilassa, jota hallinto tiukasti valvoi ja koetti tukahduttaa: strategiana on ollut oman historian kirjoittaminen suullisten tietojen pohjalta käsin.

Salmi-Niklanderin käyttämä termi puolijulkinen tuo omalta osaltaan esille koko symposiumin eetoksen julkisen ja yksityisen liukuvista rajoista ja niiden syntymisestä ihmisten toiminnassa: puheessa ja teksteissä. Mitä rajatumpi julkisen keskustelun tila on, sitä hienovaraisempaa ja kekseliäämpää on sen yhteyteen kurottaminen tai julkisen kommentoiminen yksityisen piirissä. Muistitietotutkimuksessa julkisen ja virallisen tiedon piiriin on usein pyrkimässä hiljennettyjen tai kaltoin kohdeltujen äänet, jotka ovat saattaneet elää hyvinkin rajatuissa puitteissa. Erityisen ilahduttavaa symposiumissa oli monien esitelmien tarkkasilmäisyys, joka paljasti hiljennetyissä ja rajatuissa puitteissa eläneen ja elävän diskurssin moniäänisyyden.

\section{VITTEET}

1 GULAG on lyhenne venäjänkielisistä sanoista, joiden merkitys on käännettävissä leirien keskushallinnoksi. Lyhenteellä viitataan yleisesti sekä Neuvostoliiton että sen vaikutuspiirissä olleiden maiden vanki- tai työleirijärjestelmään, jonka puitteissa muun muassa kielletystä poliittisesta toiminnasta tuomitut vangit kärsivàt pitkäaikaisia rangaistuksiaan.

\section{KiRJALlisuUs}

READ, PETER 1981: The Stolen Generations. The Removal of Aboriginal Children in New South Wales 1883 to 1969. Surry Hills NSW: Department of Aboriginal Affairs.

Filosofian tohtori Karina Lukin on folkloristiikan tutkija Helsingin yliopistossa. 